This Accepted Author Manuscript is copyrighted and published by Elsevier. It is posted here by agreement between Elsevier and University of Brasilia. Changes resulting from the publishing process - such as editing, corrections, structural formatting, and other quality control mechanisms - may not be reflected in this version of the text. The definitive version of the text was subsequently published in [Animal Reproduction Science, Volume 66, Issues 3-4, 31 May 2001, Pages 209-223, doi:10.1016/S0378-4320(01)00102-6].You may download, copy and otherwise use the AAM for non-commercial purposes provided that your license is limited by the following restrictions:

(1) You may use this AAM for non-commercial purposes only under the terms of the CC-BY-NCND license.

(2) The integrity of the work and identification of the author, copyright owner, and publisher must be preserved in any copy.

(3) You must attribute this AAM in the following format: [agreed attribution language, including link to CC BY-NC-ND license + Digital Object Identifier link to the published journal article on Elsevier's ScienceDirect ${ }^{\circledR}$ platform].

Este Manuscrito do Autor Aceito para Publicação (AAM) é protegido por direitos autorais e publicado pela Elsevier. Ele esta disponível neste Repositório, por acordo entre a Elsevier e a Universidade de Brasília. As alterações decorrentes do processo de publicação - como a edição, correção, formatação estrutural, e outros mecanismos de controle de qualidade - não estão refletidas nesta versão do texto. A versão definitiva do texto foi posteriormente publicado em [Animal Reproduction Science, Volume 66, Número 3-4, 31 Maio de 2001, Páginas 209-223, doi:10.1016/S0378-4320(01)00102-6]. Você pode baixar, copiar e utilizar de outra forma o AAM para fins não comerciais, desde que sua licença seja limitada pelas seguintes restrições:

(1) Você pode usar este AAM para fins não comerciais apenas sob os termos da licença CC- BYNC-ND.

(2) A integridade do trabalho e identificação do autor, detentor dos direitos autorais e editor deve ser preservado em qualquer cópia.

(3) Tem de atribuir este AAM no seguinte formato: [acordo na linguagem atribuída, incluindo o link para CC BY-NC-ND licença Digital + DOI do artigo publicado na revista Elsevier ScienceDirect ${ }^{\circledR}$ da plataforma]. 


\title{
Morphological and ultrastructural changes occurring during degeneration of goat preantral follicles preserved in vitro
}

\author{
J.R.V Silva \\ S.N Báo \\ C.M Lucci \\ F.C.A Carvalho \\ E.R Andrade \\ M.A.L Ferreira \\ J.R Figueiredo
}

\begin{abstract}
The present work has investigated the morphological and ultrastructural changes occurring during degeneration of goat preantral follicles preserved in vitro and showed quantitative data about the distribution of follicular degeneration types in the control and after preservation in coconut water solution or Braun-Collins solution at different temperatures $\left(4,20\right.$ or $\left.39^{\circ} \mathrm{C}\right)$ and incubation times $(4,12$ or $24 \mathrm{~h})$. At the slaughterhouse, the pair of ovaries of each animal was divided into 19 fragments. One ovarian fragment was immediately fixed (control: Time 0 ). The other 18 fragments were randomly distributed in tubes containing $2 \mathrm{ml}$ of coconut water or Braun-Collins solution at 4,20 or $39^{\circ} \mathrm{C}$ and stored for 4,12 or $24 \mathrm{~h}$. Normal preantral follicles exhibited a healthy oocyte surrounded by one or more well-organized layers of granulosa cells. The ooplasm contained numerous rounded or elongated mitochondria with continuous mitochondrial membranes. Golgi complexes were rare. Both smooth and rough endoplasmic reticulum were observed, either as isolated aggregations or complex associations with mitochondria and vesicles. Degenerated preantral follicles in the control tissue exhibited pycnotic nuclei of the oocyte, vacuolated ooplasm and normal granulosa cells. This kind of degeneration also predominated significantly $(\mathrm{P}<0.05)$ after preservation at $4^{\circ} \mathrm{C}$. In contrast, after preservation at 20 or $39^{\circ} \mathrm{C}$ a significant predominance $(\mathrm{P}<0.05)$ of preantral follicles showing a retracted oocyte and swollen granulosa cells was observed. These follicles showed large irregularity of the oocyte and nuclear outlines. The ooplasm exhibited moderate proliferation of the endoplasmic reticulum and mitochondria showed disappearance of most of the cristae and damage to the mitochondrial membrane. Some follicles had numerous vacuoles in the ooplasm. Granulosa cells were spread and a low density of organelles was observed. The alterations in follicular structure progressed with an increase of temperature from 20 to $39^{\circ} \mathrm{C}$ as well as with an increase of the incubation time from 4 to 12 , or $24 \mathrm{~h}$. In conclusion, the present study shows for the first time that initial proliferation of the endoplasmic reticulum and damage to mitochondria are the first signs of degeneration in goat preantral follicles during storage in vitro.
\end{abstract}

Keywords: Goat; Preantral follicle; Preservation; Ultrastructural; Morphology

\section{Introduction}

At birth the mammalian ovary contains many thousands of preantral follicles but the vast majority become atretic during their growth and maturation. As a result relatively few viable oocytes are produced during the reproductive lifespan of the female (Carroll et al., 
1990). The techniques developed for the isolation (Figueiredo et al., 1993 and Lucci et al., 1999), culture (Figueiredo et al., 1994) and cryopreservation (Carroll et al., 1990) of preantral follicles offers a means to utilize large numbers of preantral follicles in reproductive programs. These techniques have been successfully applied in laboratory species. For example, mice offspring have resulted from preantral follicles that were isolated, cryopreserved and cultured in vitro (Carroll et al., 1990).

In farm animals, the donor of the ovarian follicles is usually not housed near the laboratory where the research is done. Therefore, preservation of the follicles during transport from the field to the laboratory becomes a major concern. Recently, we described the beneficial effects of coconut water and Braun-Collins solutions on the preservation of caprine preantral follicles (Silva et al., 1999 and Silva et al., 2000). Coconut water and Collins solutions have been successfully used for semen (Nunes, 1998) and organ (liver: Adam et al., 1996; lung: Fukuse et al., 1996; kidney: Savioz et al., 1996) preservation, respectively. The preservation of preantral follicles is of obvious importance for the maintenance of follicular morphology during transportation of ovaries to the laboratory, which is necessary to provide healthy oocytes for in vitro growth and maturation. Thus, the need for an understanding of the ultrastructural events occurring in preantral follicles during preservation in vitro is important to develop suitable preservation systems as well as to comprehend follicular atresia. Furthermore, the ultrastructural features of cattle (Fair et al., 1997), sheep (Tassel and Kennedy, 1980), human (Hertig and Adams, 1967 and Oktay et al., 1997), guinea pig (Adams and Hertig, 1964) and goat (Sharma et al., 1994 and Lucci et al., 2001) preantral follicles have been described in several papers. In addition, Tassel and Kennedy (1980) and van den Hurk et al. (1998) showed the ultrastructural features of preantral follicles that underwent degeneration in vivo. However, the sequence of events taking place during degeneration in goat preantral follicles preserved in vitro is presently unknown.

The aims of the present study was to describe the morphological and ultrastructural changes occurring during degeneration of goat preantral follicles preserved in vitro and to show quantitative data about the distribution of follicular degeneration types in the control and after preservation in coconut water or Braun-Collins solutions at different temperatures and incubation times. 


\section{Material and methods}

\subsection{Source of ovaries}

Ovaries $(n=10)$ from five adult mixed breed goats were collected at a local slaughterhouse. Under aseptic conditions, the ovaries were stripped of surrounding fat tissue and ligaments and processed as described in the experimental protocol.

\subsection{Media}

The media tested were: (1) commercial Braun-Collins solution (osmolarity: 401 mOsm/l; pH: 7.2 - Laboratory B. Braun S.A, Rio de Janeiro, Brazil), and (2) coconut water solution composed of two parts of filtered coconut water, one part of purified water and one part of $5 \%$ sodium citrate - final osmolarity: $300 \mathrm{mOsm} / \mathrm{I}$ and pH: 6.8 (Nunes, 1998). Coconut water was obtained from coconuts (6-month-old) collected from the green beach variety of the coconut-palm (Cocus nucifera).

\subsection{Experimental protocol}

In the slaughterhouse, the pair of ovaries from each animal was divided into 19 fragments. Following this, one ovarian fragment was taken randomly, a small piece removed for electron microscopy, and the remainder immediately fixed for histological examination (control: Treatment 1 and Time 0). The other 18 fragments were randomly distributed in tubes containing $2 \mathrm{ml}$ of coconut water or Braun-Collins solution at 4, 20 or $39^{\circ} \mathrm{C}$ and stored for 4,12 or $24 \mathrm{~h}$ (Treatments 2-19) as shown in Fig. 1. The temperatures were maintained using thermosflasks filled with water at 4,20 or $39^{\circ} \mathrm{C}$. For each treatment, parameters such as temperature, osmolarity and $\mathrm{pH}$ of the solutions were monitored at the beginning and at the end of the treatments. Each treatment was repeated five times. 


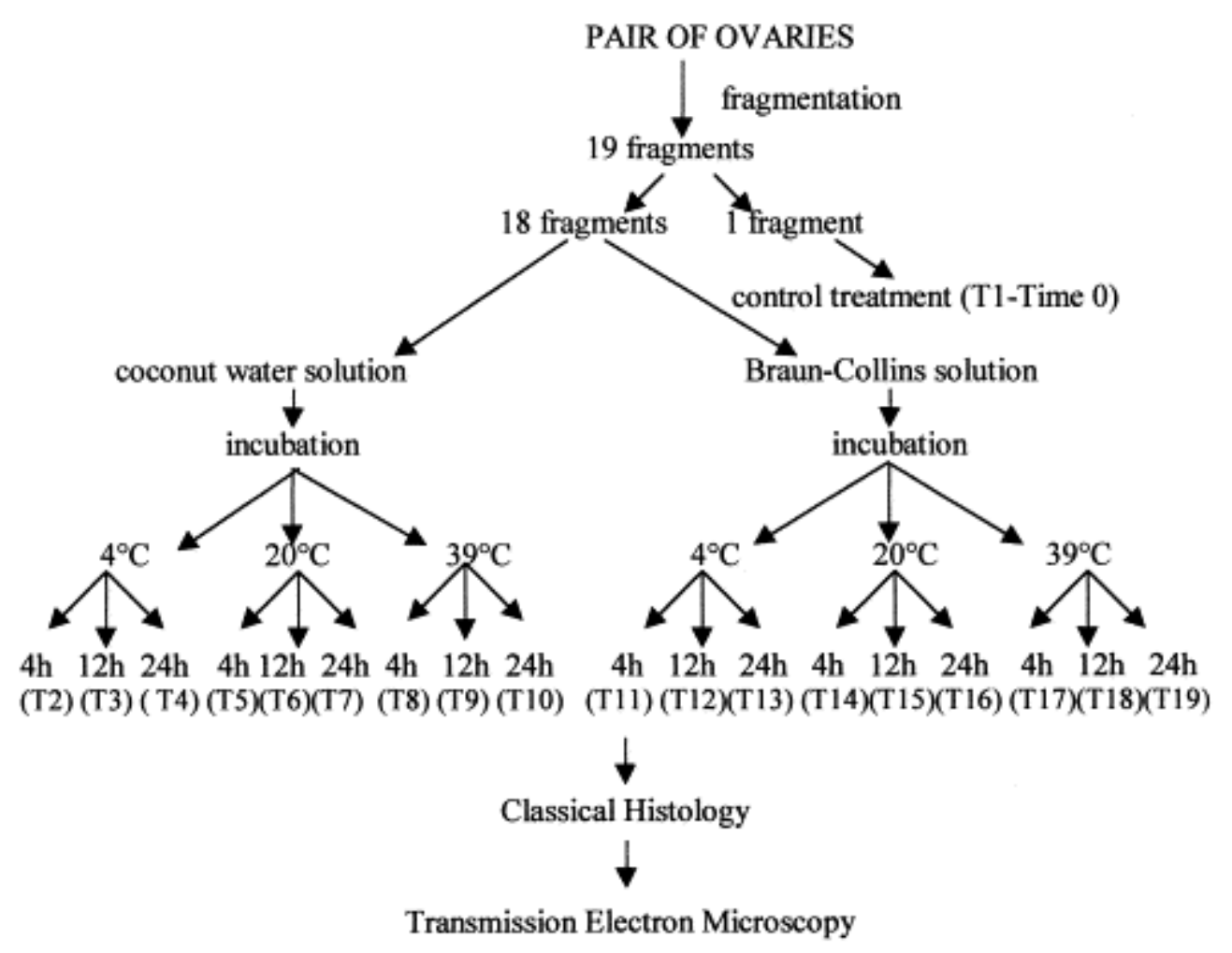

Fig. 1. General experimental protocol for preservation of caprine preantral follicles.

\subsection{Light microscopy}

To evaluate the morphology of the caprine preantral follicles, the ovarian fragments from the different treatments were processed as follows. Small pieces of the ovarian fragments from each treatment, including the control, were removed for electron microscopy with the remainder being fixed individually in Bouins fluid for $12 \mathrm{~h}$. Following this, they were dehydrated in a graded series of ethanol and embedded in paraffin wax. Sections of $7 \mu \mathrm{m}$ were stained with hematoxylin and eosin and examined by light microscopy (Axiophot: Zeiss, Germany). The nucleus of the oocyte was used as a marker for analyzing follicles. Number of preantral follicles ranged from 163 to 249 in each treatment.

The follicular morphology was evaluated based on the integrity of the basement membrane, cellular density, cellular swelling, presence or absence of pycnotic bodies and retraction of the oocyte. Based on these variables, preantral follicles were classified as morphologically normal, degenerated Type 1 follicles (only the oocyte was degenerated), degenerated Type 2A follicles (early stage of degeneration of both oocyte and granulosa cells) and degenerated Type 2B follicles (advanced stage of degeneration of both oocyte and granulosa cells). These four classifications were assigned on a basis of degeneration that 
occurred as result of in vitro storage as well as in normal or degenerated follicles observed in the control.

\subsection{Transmission electron microscopy}

Ultrastructural analysis was performed using preantral follicles considered morphologically normal as well as in degenerated follicles after preservation. Briefly, small pieces of ovarian cortex were fixed in a solution containing $2 \%$ paraformaldehyde and $2.5 \%$ glutaraldehyde in $0.1 \mathrm{M}$ sodium cacodylate buffer $\mathrm{pH}$ 7.2. After fixation, the specimens were rinsed in buffer and post-fixed in $1 \%$ osmium tetroxide, $0.8 \%$ potassium ferricyanide and $5 \mathrm{mM}$ $\mathrm{CaCl} 2$ in $0.1 \mathrm{M}$ sodium cacodylate buffer. Subsequently the samples were dehydrated in acetone and embedded in Spurr. Thin sections $(65 \mathrm{~nm})$ were prepared when an oocyte nucleus appeared in the semi-thin sections $(3 \mu \mathrm{m})$. Semi-thin sections were stained with toluidine blue while thin sections were contrasted with uranyl acetate and lead citrate, and examined using Jeol $100 \mathrm{C}$ and Zeiss 912 transmission electron microscopes.

\subsection{Statistical analysis of data}

For each treatment, values of degenerated preantral follicles from five ovarian fragments were pooled. The percentages of degenerated follicles were compared using a Chisquared test (Instat for Macintosh). Values were considered statistically significant when $\mathrm{P}<0.05$.

\section{Results}

\subsection{Light microscopy}

Normal preserved preantral follicles exhibited a healthy spherical or oval oocyte with a large central or eccentrically located nucleus. Granulosa cells, well-organized in layers, without pycnotic nuclei were observed surrounding the oocyte (Fig. 2A). Degenerated Type 1 follicles exhibited an oocyte with a pycnotic nucleus and well-organized granulosa cells without pycnotic nuclei (Fig. 2B). In degenerated Type 2A follicles a lightly retracted oocyte and swollen granulosa cells were observed (Fig. 2C). Moreover, degenerated Type 2B follicles had a 
retracted oocyte, with or without a pycnotic nucleus, strongly eosinophilic cytoplasm and disorganized, low density swollen granulosa cells (Fig. 2D).
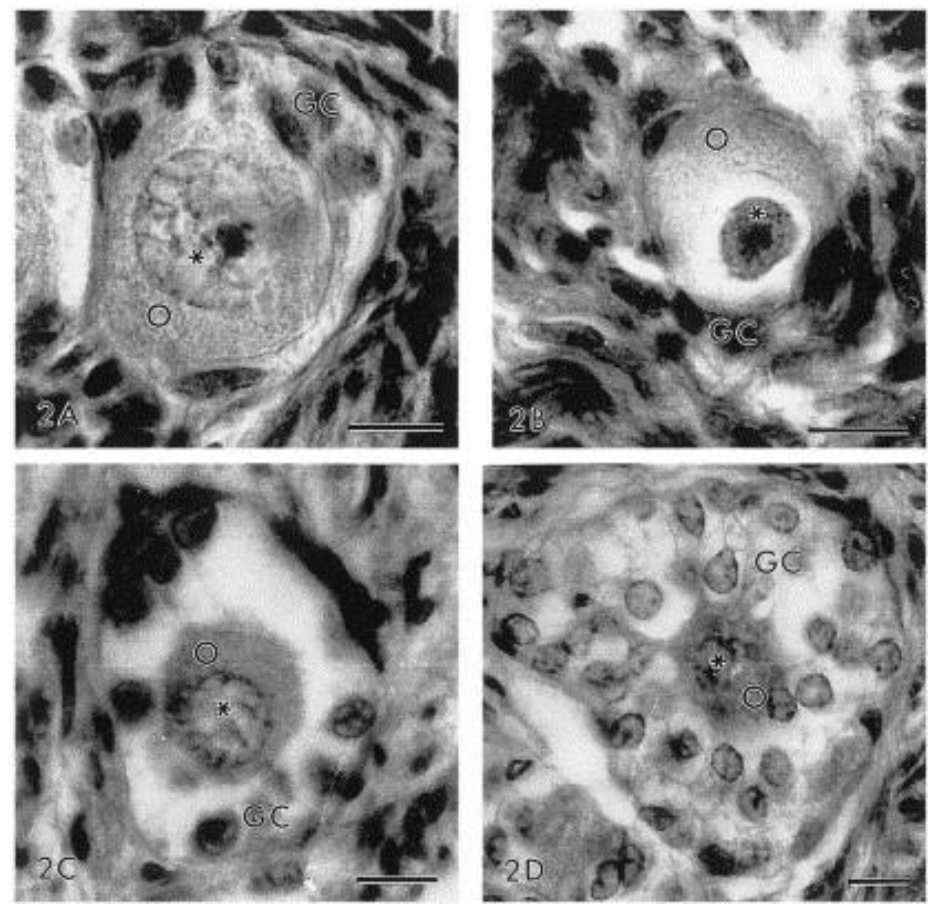

Fig. 2. Histological sections of (A) normal, (B) degenerated Type 1, (C) degenerated Type 2A and (D) degenerated Type 2B preantral follicles. O: oocyte; $*$ : nucleus; GC: granulosa cells. Bar=10 $\mu \mathrm{m}$.

\subsection{Ultrastructural aspects of preantral follicles after preservation}

Normal preantral follicles exhibited sparse vesicles spread throughout the cytoplasm in all the oocytes. The cytoplasm also contained numerous rounded mitochondria with peripheral cristae and continuous mitochondrial membranes, although there were occasional elongated forms with parallel cristae. Golgi complexes were rarely observed. Both smooth and rough endoplasmic reticulum were present, either as isolated aggregations or as complex associations with mitochondria and vesicles (Fig. 3). Granulosa cells had irregularly-shaped nuclei, with a high nuclear-to-cytoplasm ratio. The cytoplasm contained a great number of elongated mitochondria with lamellar cristae and well-developed rough endoplasmic reticulum (Fig. 3). These features were observed in preantral follicles preserved in coconut water solution at $4^{\circ} \mathrm{C}$ for up to $24 \mathrm{~h}$ and in Braun-Collins solution for up to $12 \mathrm{~h}$, as well as in follicles from control. 


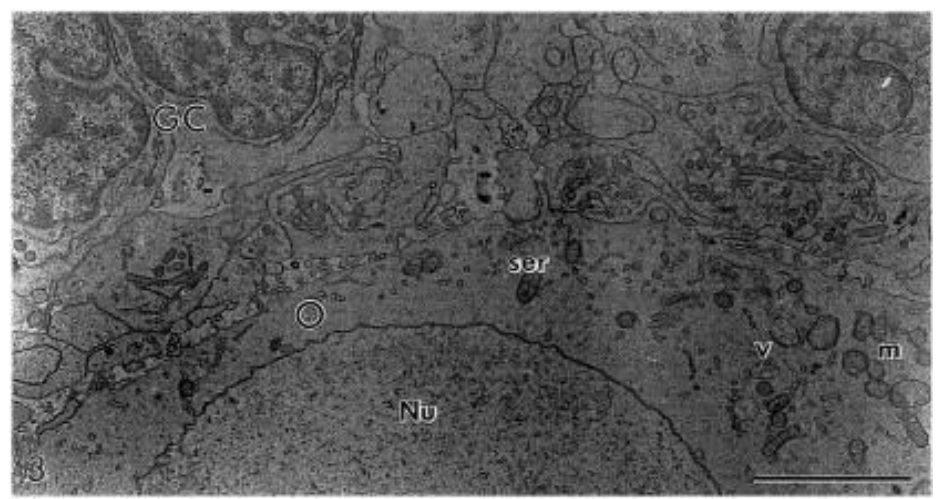

Fig. 3. Electron micrograph of a normal preantral follicle from the control group. O: oocyte; Nu: nucleus of oocyte; GC: granulosa cells; m: mitochondria; ser: smooth endoplasmic reticulum; v: vesicles. Bar=5 $\mu \mathrm{m}$.

In some treatments follicles seemed to be well preserved according to histological analysis, however, transmission electron microscopy revealed some discreet changes in their ultrastructure (apparently normal at semi-thin sections). These changes suggest an initial degeneration that was observed in follicles preserved in Braun-Collins solution at $4^{\circ} \mathrm{C}$ for $24 \mathrm{~h}$, in both solutions at $20^{\circ} \mathrm{C}$ at all incubation times, and in coconut water solution at $39^{\circ} \mathrm{C}$ for $4 \mathrm{~h}$. These follicles showed a large number of vesicles spread throughout the cytoplasm in all oocytes (Fig. 4). In addition, initial signs of proliferation of the endoplasmic reticulum and damage to mitochondrial membranes and cristae were observed. Granulosa cells had a swollen aspect, with a low density of organelles present in their cytoplasm (Fig. 5). The progression of these alterations led to follicles with a larger number of vesicles in the oocyte cytoplasm, and with damaged mitochondria, without cristae and with flaked content, closely associated with the smooth endoplasmic reticulum (Fig. 6). The oocyte nucleus appeared misshapen and retracted with a wavy membrane.

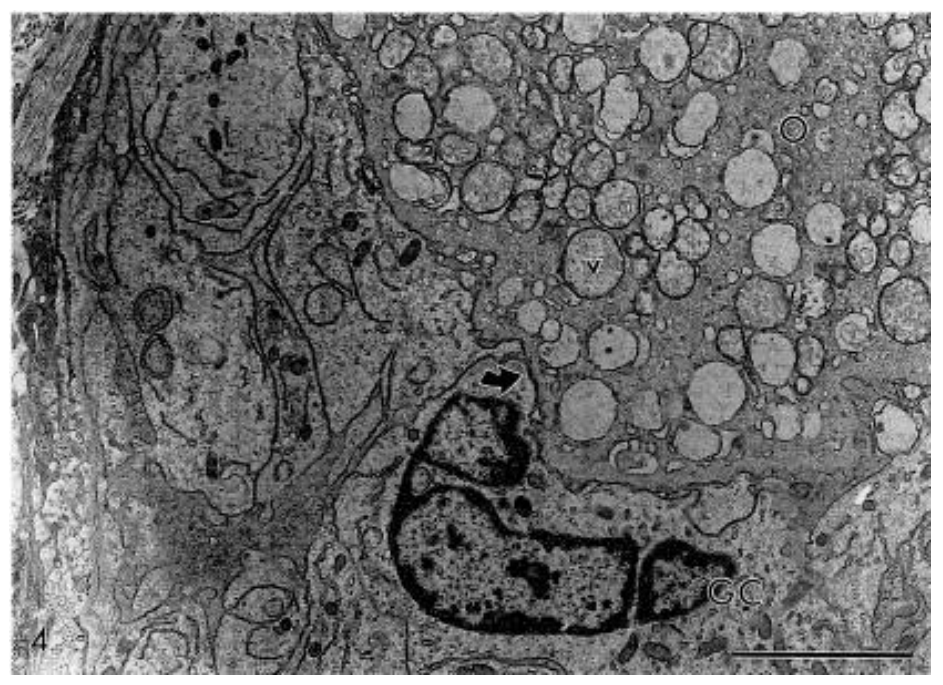

Fig. 4. Electron micrograph of a preantral follicle preserved in coconut water solution at $20^{\circ} \mathrm{C}$ for $4 \mathrm{~h}$ apparently normal at the semi-thin section. Note the great number of vesicles in the oocyte cytoplasm and the irregular oocyte outlines (arrow). O: oocyte; GC: granulosa cells; v: vacuoles. Bar=5 $\mu \mathrm{m}$. 


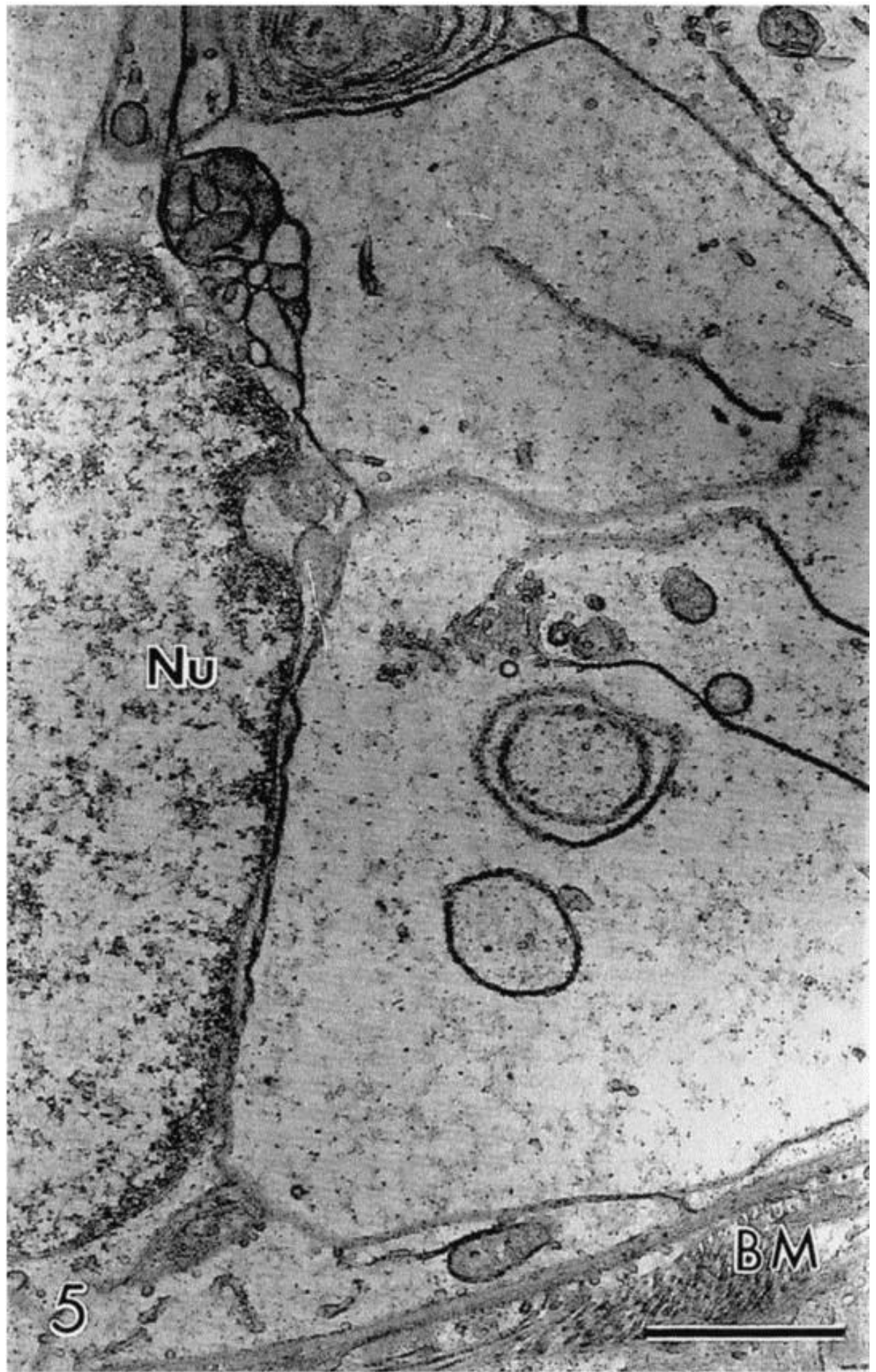

Fig. 5. Detail of a granulosa cell showing low cytoplasmic density. Apparently normal follicle at the semithin section preserved in Braun-Collins solution at $20^{\circ} \mathrm{C}$ for $12 \mathrm{~h}$. Nu: nucleus of granulosa cell; BM: basement membrane. Bar $=2 \mu \mathrm{m}$. 


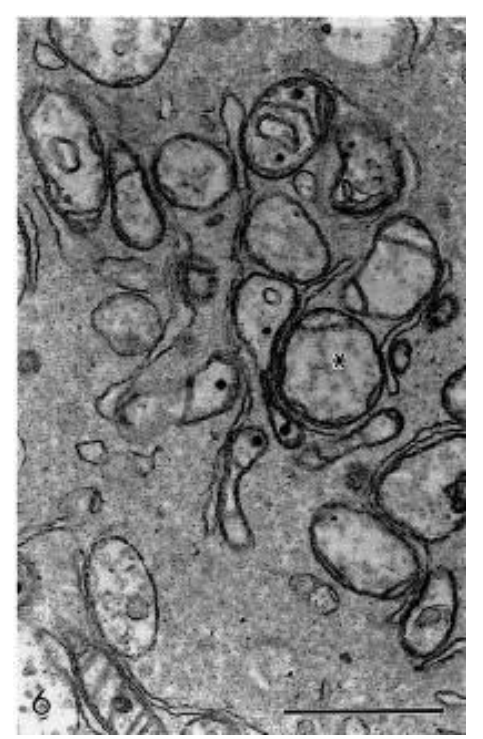

Fig. 6. Detail of oocyte cytoplasm showing mitochondria closely associated with smooth endoplasmic reticulum. Note the mitochondrial flaked content $(*)$. Bar $=1 \mu \mathrm{m}$.

Degenerated Type 1 follicles showed similar alterations to those observed in apparently normal preantral follicles (data not shown). Degenerated Type $2 \mathrm{~A}$ follicles contained a retracted oocyte and large irregularity of the follicular, oocyte and nuclear outlines (Fig. 7), besides the above described changes. The nuclear membrane was broken in some follicles. Granulosa cells became disorganized and some disappeared leaving a vacated space. Many times, the connection between the oocyte and granulosa cells did not exist (data not shown).

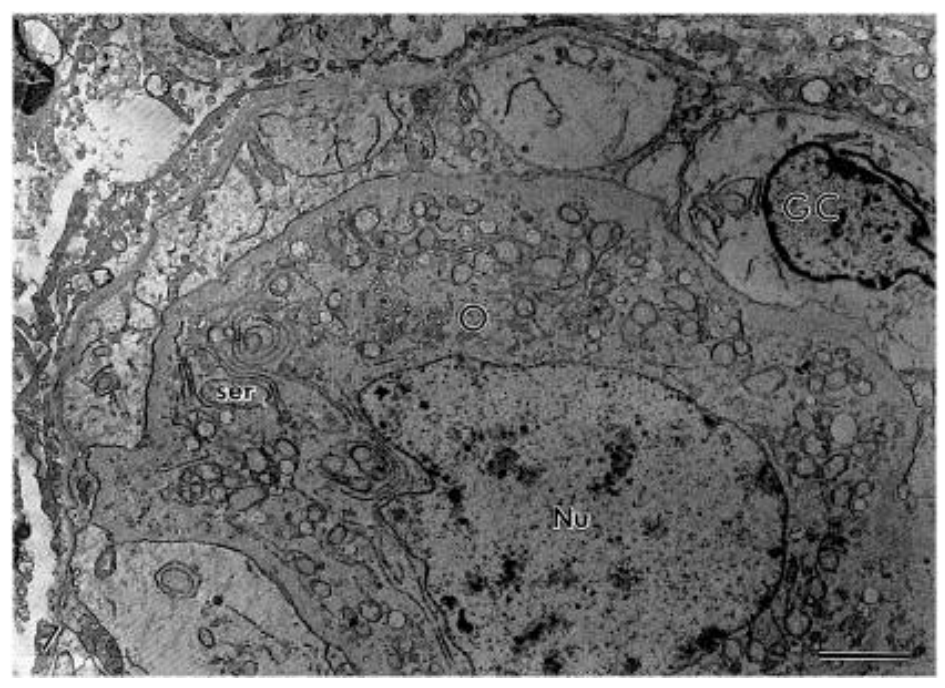

Fig. 7. Electron micrograph of a degenerated Type $2 \mathrm{~A}$ follicle preserved in coconut water solution at $20^{\circ} \mathrm{C}$ for $24 \mathrm{~h}$. Note the retracted oocyte and large irregularity of the follicular, oocyte and nuclear outlines and the cytoplasmic low density of granulosa cells. O: oocyte; Nu: nucleus of oocyte; GC: granulosa cell; ser: smooth endoplasmic reticulum. Bar=5 $\mu \mathrm{m}$.

Degenerated Type 2B follicles exhibited a progression of the changes described above. The oocyte cytoplasm was extremely vacuolated, with the vacuoles often fusing to produce a greater vacated area (Fig. 8). Sometimes the cytoplasm appeared clotted, possibly as a result 
of nuclear content leak (data not shown). At this stage, organelles were generally no longer recognizable. However, where it was possible to discern, mitochondria appeared to be closely associated with large formations of swollen membranes of the endoplasmic reticulum in a parallel array. In these follicles, some granulosa cells were completely fragmented. In only one follicle was the basement membrane broken (Fig. 9).

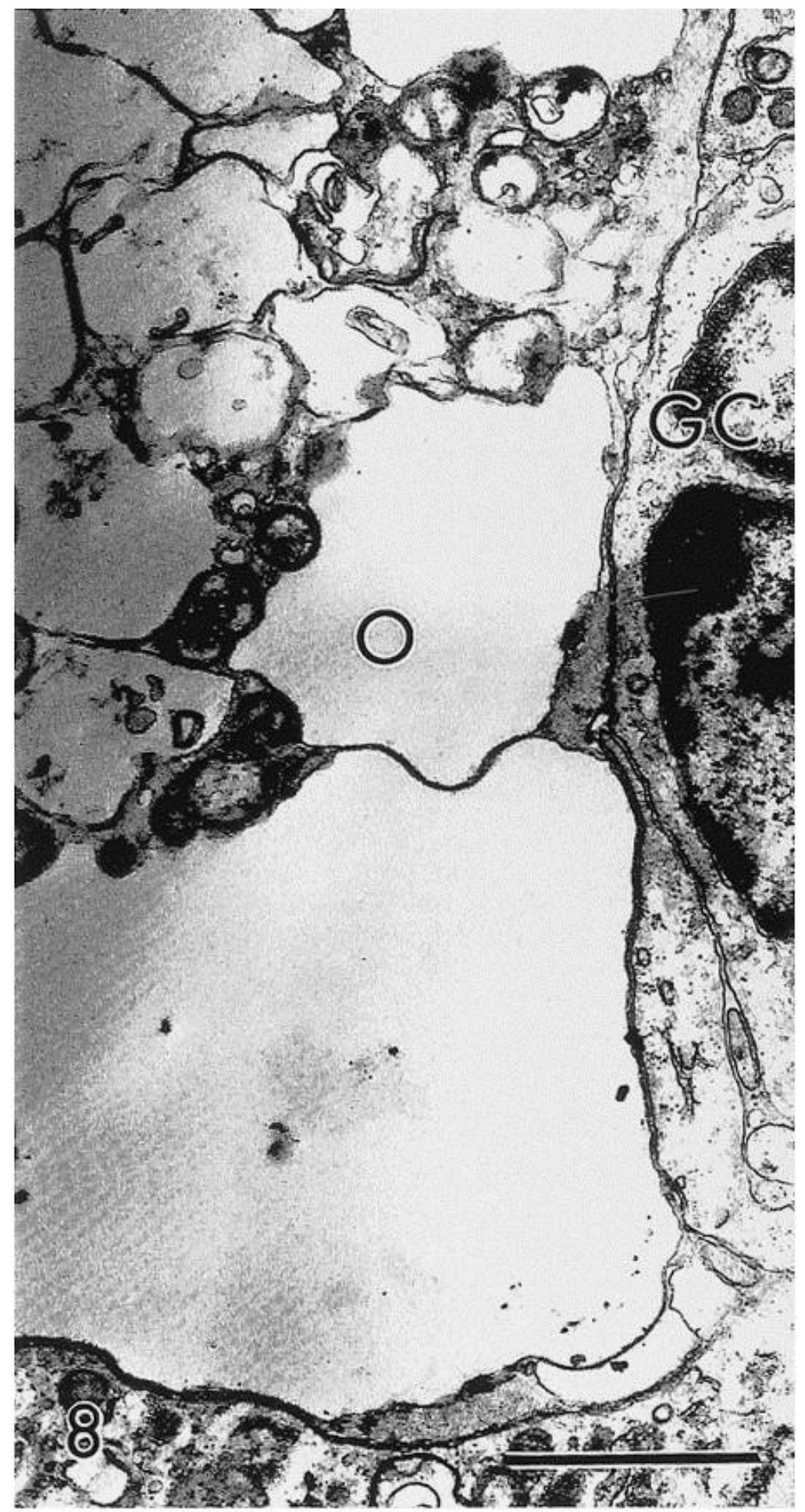

Fig. 8. Detail of the oocyte cytoplasm of a degenerated Type $2 \mathrm{~B}$ follicle preserved in coconut water solution at $39^{\circ} \mathrm{C}$ for $4 \mathrm{~h}$. Note the extreme vacuolization and the great holes present in the cytoplasm without any recognizable organelle. O: oocyte; GC: granulosa cell. Bar=2 $\mu \mathrm{m}$. 


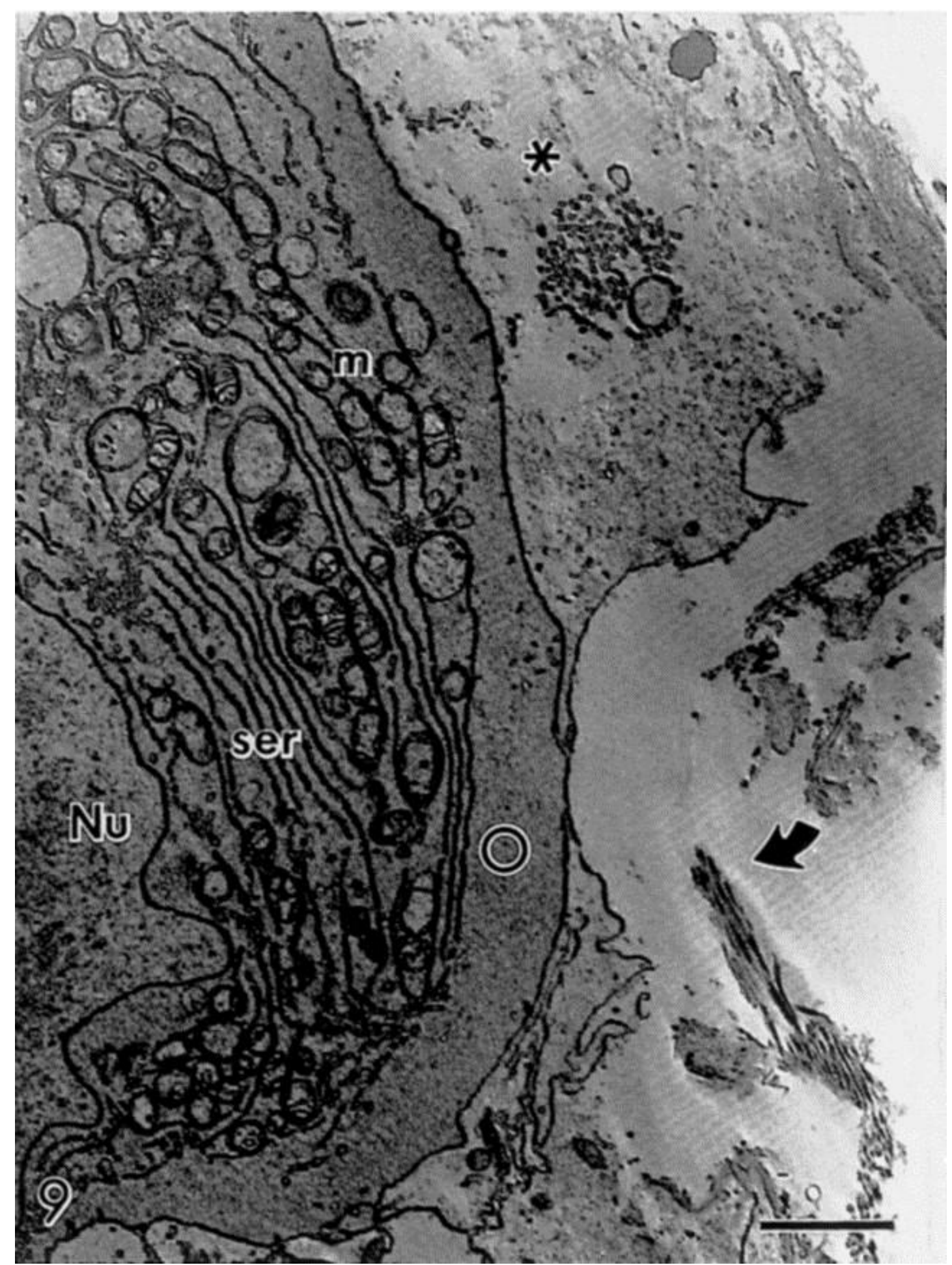

Fig. 9. Electron micrograph of a degenerated Type $2 \mathrm{~B}$ follicle preserved in Braun-Collins solution at $39^{\circ} \mathrm{C}$ for 4 h. O: oocyte; Nu: nucleus of oocyte; ser: smooth endoplasmic reticulum; m: mitochondria. Note a completely fragmented granulosa cell $(*)$. The arrow marks the broken basement membrane. Bar=2 $\mu \mathrm{m}$. 


\subsection{Distribution of follicular degeneration types in the control and other treatments}

A total of 3826 preantral follicles were examined by histological analysis. Number of follicles ranged from 163 to 249 in each treatment. Morphologically normal follicles were observed by histological analysis in all treatments, except after preservation in Braun-Collins solution at $39^{\circ} \mathrm{C}$ for $12 \mathrm{~h}$ and in both solutions at $39^{\circ} \mathrm{C}$ for $24 \mathrm{~h}$. Of the degenerated follicles, in the control as well as after storage in both solutions at $4^{\circ} \mathrm{C}$ for $4 \mathrm{~h}$ only degenerated Type 1 follicles was observed (Table 1 and Table 2). A significant predominance $(P<0.05)$ of degenerated Type 1 follicles when compared with degenerated Types $2 \mathrm{~A}$ and $2 \mathrm{~B}$ follicles was observed after storage at $4^{\circ} \mathrm{C}$ for 12 or $24 \mathrm{~h}$, in both solutions. In contrast, a significant predominance $(P<0.05)$ of degenerated Types $2 A$ and $2 B$ follicles was observed after storage in both solutions at 20 or $39^{\circ} \mathrm{C}$, when compared with degenerated Type 1 follicles ( Table 1 and Table 2). Compared with degenerated Type 2B follicles, a significant predominance $(P<0.05)$ of degenerated Type $2 \mathrm{~A}$ follicles was observed after preservation in coconut water solution at $20^{\circ} \mathrm{C}$ for $12 \mathrm{~h}$ or at $39^{\circ} \mathrm{C}$ for $4 \mathrm{~h} \mathrm{(Table} 1$ ) and in Braun-Collins solution at 20 and $39^{\circ} \mathrm{C}$ for $4 \mathrm{~h} \mathrm{(}$ Table 2). A significantly greater $(P<0.05)$ percentage of degenerated Type $2 B$ follicles was found after storage in coconut water solution at 20 or $39^{\circ} \mathrm{C}$ for $24 \mathrm{~h}$ ( Table 1) and in BraunCollins solution at 20 or $39^{\circ} \mathrm{C}$ for 12 and $24 \mathrm{~h}$ ( Table 2).

Table 1.

Percentage distribution of degenerated Types $1,2 \mathrm{~A}$ and $2 \mathrm{~B}$ follicles from control and after preservation in different treatments in coconut water solution, ${ }^{a b c}$

\begin{tabular}{llll}
\hline Treatments & $\begin{array}{l}\text { Degenerated Type 1 } \\
\text { follicles }(\%)(n)\end{array}$ & $\begin{array}{l}\text { Degenerated Type 2A } \\
\text { follicles }(\%)(n)\end{array}$ & $\begin{array}{l}\text { Degenerated Type 2B } \\
\text { follicles }(\%)(n)\end{array}$ \\
\hline Control & $13.2 \mathrm{a}(28 / 212)$ & $0 \mathrm{~b}(0 / 212)$ & $0 \mathrm{~b}(0 / 212)$ \\
$4^{\circ} \mathrm{C}-4 \mathrm{~h}$ & $7.5 \mathrm{aAG}(18 / 240)$ & $0 \mathrm{bAI}(0 / 240)$ & $0 \mathrm{bH}(0 / 240)$ \\
$4^{\circ} \mathrm{C}-12 \mathrm{~h}$ & $8.5 \mathrm{aAG}(14 / 165)$ & $1.8 \mathrm{bAI}(3 / 165)$ & $0 \mathrm{bI}(0 / 65)$ \\
$4^{\circ} \mathrm{C}-24 \mathrm{~h}$ & $8.0 \mathrm{aAG}(13 / 163)$ & $0.6 \mathrm{bAH}(01 / 163)$ & $0 \mathrm{bI}(0 / 163)$ \\
$20^{\circ} \mathrm{C}-4 \mathrm{~h}$ & $0 \mathrm{bH}(0 / 163)$ & $6.7 \mathrm{aCH}(11 / 163)$ & $6.1 \mathrm{aCG}(10 / 163)$ \\
$20^{\circ} \mathrm{C}-12 \mathrm{~h}$ & $0 \mathrm{cH}(0 / 234)$ & $15.8 \mathrm{aBH}(37 / 234)$ & $6.0 \mathrm{bBH}(14 / 234)$ \\
$20^{\circ} \mathrm{C}-24 \mathrm{~h}$ & $0 \mathrm{cH}(0 / 249)$ & $36.9 \mathrm{bAG}(92 / 249)$ & $51.4 \mathrm{aAH}(128 / 249)$ \\
$39^{\circ} \mathrm{C}-4 \mathrm{~h}$ & $0 \mathrm{cH}(0 / 194)$ & $60.3 \mathrm{aAG}(117 / 194)$ & $3.1 \mathrm{bCG}(6 / 194)$ \\
$39^{\circ} \mathrm{C}-12 \mathrm{~h}$ & $0 \mathrm{bH}(0 / 239)$ & $45.2 \mathrm{aBG}(108 / 239)$ & $50.6 \mathrm{aBG}(121 / 239)$ \\
$39^{\circ} \mathrm{C}-24 \mathrm{~h}$ & $0 \mathrm{cH}(0 / 172)$ & $37.2 \mathrm{bCG}(64 / 172)$ & $62.8 \mathrm{aAG}(108 / 172)$ \\
\hline
\end{tabular}

\footnotetext{
${ }^{a}$ Values with different letters $(a, b, c)$ in the same row show significant differences $(P<0.05)$.

${ }^{b}$ Values within columns with different letters $(A, B, C)$ at the same preservation temperature show significant differences among incubation times $(P<0.05)$.

${ }^{c}$ Values within columns with different letters $(G, H, I)$ at the same incubation time show significant differences among preservation temperatures $(P<0.05)$.
} 


\section{Table 2}

Percentage distribution of degenerated Types 1, 2A and 2B follicles from control and after preservation in different treatments in Braun-Collins solution ${ }^{\mathrm{a}, \mathrm{b}, \mathrm{c}}$

\begin{tabular}{llcc}
\hline Treatments & $\begin{array}{l}\text { Degenerated Type } 1 \\
\text { follicles }(\%)(n)\end{array}$ & $\begin{array}{l}\text { Degenerated Type 2A } \\
\text { follicles }(\%)(n)\end{array}$ & $\begin{array}{l}\text { Degenerated Type 2B } \\
\text { follicles }(\%)(n)\end{array}$ \\
\hline Control & $13.2 \mathrm{a}(28 / 212)$ & $0 \mathrm{~b}(0 / 212)$ & $0 \mathrm{~b}(0 / 212)$ \\
$4^{\circ} \mathrm{C}-4 \mathrm{~h}$ & $12.4 \mathrm{aAG}(21 / 169)$ & $0 \mathrm{bBI}(0 / 169)$ & $0 \mathrm{bBI}(0 / 169)$ \\
$4^{\circ} \mathrm{C}-12 \mathrm{~h}$ & $11.4 \mathrm{aAG}(24 / 211)$ & $1.4 \mathrm{bABH}(3 / 211)$ & $1.4 \mathrm{bABI}(3 / 211)$ \\
$4^{\circ} \mathrm{C}-24 \mathrm{~h}$ & $9.9 \mathrm{aAG}(21 / 212)$ & $4.7 \mathrm{bAH}(10 / 212)$ & $3.3 \mathrm{bAI}(7 / 212)$ \\
$20^{\circ} \mathrm{C}-4 \mathrm{~h}$ & $0.6 \mathrm{cAH}(1 / 177)$ & $40.1 \mathrm{aAH}(71 / 177)$ & $8.5 \mathrm{bCH}(15 / 177)$ \\
$20^{\circ} \mathrm{C}-12 \mathrm{~h}$ & $0.4 \mathrm{cAH}(1 / 235)$ & $33.6 \mathrm{bABG}(79 / 235)$ & $59.1 \mathrm{aBH}(139 / 235)$ \\
$20^{\circ} \mathrm{C}-24 \mathrm{~h}$ & $0 \mathrm{cAH}(0 / 225)$ & $27.6 \mathrm{bBG}(62 / 225)$ & $72.4 \mathrm{aAH}(163 / 225)$ \\
$39^{\circ} \mathrm{C}-4 \mathrm{~h}$ & $0.5 \mathrm{cAH}(1 / 196)$ & $50.0 \mathrm{aAG}(98 / 196)$ & $39.3 \mathrm{bCG}(77 / 196)$ \\
$39^{\circ} \mathrm{C}-12 \mathrm{~h}$ & $0 \mathrm{cAH}(0 / 182)$ & $3.3 \mathrm{bBH}(6 / 182)$ & $96.7 \mathrm{aBG}(176 / 182)$ \\
$39^{\circ} \mathrm{C}-24 \mathrm{~h}$ & $0 \mathrm{bAH}(0 / 188)$ & $0 \mathrm{bCl}(0 / 188)$ & $100 \mathrm{aAG}(188 / 188)$ \\
\hline
\end{tabular}

${ }^{a}$ Values with different letters $(a, b, c)$ at the same row show significant differences $(P<0.05)$.

${ }^{b}$ Values within columns with different letters $(A, B, C)$ at the same preservation temperature show significant differences among incubation times $(P<0.05)$.

${ }^{c}$ Values within columns with different letters $(G, H, I)$ at the same incubation time show significant differences among preservation temperatures $(P<0.05)$.

There was no effect of incubation time on the percentage of degenerated Types $1,2 \mathrm{~A}$ and $2 \mathrm{~B}$ follicles using both solutions at $4^{\circ} \mathrm{C}$ (Table 1 and Table 2), except for Braun-Collins solution at $24 \mathrm{~h}$, which increased significantly $(P<0.05)$ the percentage of degenerated Types $2 \mathrm{~A}$ and $2 \mathrm{~B}$ follicles. In contrast for coconut water solution ( Table 1$)$, there was a significant $(P<0.05)$ increase $\left(20^{\circ} \mathrm{C}\right)$ and decrease $\left(39^{\circ} \mathrm{C}\right)$ of the percentages of degenerated Type $2 \mathrm{~A}$ follicles with the increase of incubation time, respectively. Similar results were obtained for Braun-Collins solution ( Table 2), except for the storage temperature of $20^{\circ} \mathrm{C}$, at which similar $-12 \mathrm{~h}$ $(P>0.05)$ and significantly lower $-24 \mathrm{~h}(\mathrm{P}<0.05)$ percentages of degenerated Type $2 \mathrm{~A}$ follicles were observed when compared with values obtained at $20^{\circ} \mathrm{C}$ for $4 \mathrm{~h}$. In addition, there was a progressive increase of the percentage of degenerated Type $2 \mathrm{~B}$ follicles with the increase of the incubation times $(P<0.05)$ in the fragments stored at 20 or $39^{\circ} \mathrm{C}$, in both solutions ( Table 1 and Table 2).

With regard to the effect of temperature, a significant reduction $(P<0.05)$ of degenerated Type 1 follicles was observed with the increase of temperature from 4 to 20 and $39^{\circ} \mathrm{C}$ at all incubation times in both solutions. The percentages of degenerated Types $2 \mathrm{~A}$ and $2 \mathrm{~B}$ follicles increased significantly $(P<0.05)$ with the increase of temperature from 4 to 20 and $39^{\circ} \mathrm{C}$ for both solutions ( Table 1 and Table 2), except for the similar percentages $(P>0.05)$ of degenerated Type $2 \mathrm{~A}$ follicles after storage in coconut water solution for $24 \mathrm{~h}$ at 20 and $39^{\circ} \mathrm{C}$ ( Table 1), and for a significant reduction $(P<0.05)$ of the percentages of degenerated Type $2 A$ follicles after preservation in Braun-Collins solution for 12 and $24 \mathrm{~h}$ with the increase of temperature from 20 to $39^{\circ} \mathrm{C}$ ( Table 2). 


\section{Discussion}

The present study shows for the first time the morphological and ultrastructural changes occurring during degeneration of goat preantral follicles in ovarian tissue fragments preserved in vitro in coconut water or Braun-Collins solutions at different temperatures and incubation times.

Ultrastructural analysis of goat normal preantral follicles preserved in vitro showed that the ooplasm contains smooth (SER) and rough (SER) endoplasmic reticulum associated with round or elongated mitochondria and vesicles. Such a feature is commonly observed in fresh preantral follicles of goats (Sharma et al., 1994 and Lucci et al., 2001) and other species (cattle: van Wezel and Rodgers, 1996 and Fair et al., 1997; sheep: Cran et al., 1980 and Tassel and Kennedy, 1980; guinea pig: Adams and Hertig, 1964; human: Hertig and Adams, 1967; and mouse: Wassarman and Josefowicz, 1978). The association of endoplasmic reticulum with mitochondria and vesicles suggests a mechanism for the transport of substrates into the mitochondria. Furthermore, vesicles containing a variety of internal substances also appear to be evidence of transport to the paranuclear metabolic center from the oocyte surface or vice versa (Hertig and Adams, 1967).

The preantral follicles preserved in Braun-Collins solution at $4^{\circ} \mathrm{C}$ for $24 \mathrm{~h}$ exhibited numerous vacuoles in the ooplasm as revealed by ultrastructural analysis. Tassel and Kennedy (1980) and van den Hurk et al. (1998) emphasized that oocytes showing signs of atresia in vivo contain numerous vacuoles. The cytoplasmic vacuoles are also a characteristic sign of degeneration in granulosa (Hay et al., 1976) and cumulus cells (Assey et al., 1994) during degeneration in vivo and may represent endoplasmic reticulum swelling. Conversely, these vacuoles may represent altered mitochondria, as observed in cryopreserved bovine oocytes by Fuku et al. (1995). The proliferation of endoplasmic reticulum and damage to the mitochondria were observed in degenerated follicles as well as in apparently normal follicles after preservation in both solutions at 20 and $39^{\circ} \mathrm{C}$. These changes increase with incubation time, probably indicating that they were induced by the preservation condition.

Degenerated Types 2A and 2B follicles contained aggregates of cytoplasmic organelles, proliferation of the endoplasmic reticulum and mitochondrial damage. In subordinate oocytes (Assey et al., 1994) and thecal cells (O'Shea et al., 1978) large aggregates of endoplasmic reticulum were observed, providing evidence of atresia. In addition, bovine oocytes showed large aggregates of SER surrounded by mitochondria after $48 \mathrm{~h}$ of culture (Hyttel et al., 1986). Kruip et al. (1983) suggesting the existence of metabolic units in which vesicles and 
mitochondria are combined via the SER. Thus, the clustering of organelles appears to indicate a decrease in oocyte metabolism during culture (Hyttel et al., 1986). Under our experimental conditions, the proliferation of endoplasmic reticulum may indicate an attempted adaptation to adverse conditions throughout the preservation period. With regard to mitochondrial damage, according to Butler (1970) the changes at the concentrations of intracellular $\mathrm{K}+, \mathrm{Ca}+$ and $\mathrm{P}+$ induce mitochondrial swelling and consequently disappearance of most of the cristae. In addition, Green and Reed (1998) showed that the opening of non-selective channels in the inner mitochondrial membrane allows for an equilibration of ions with the matrix and intermembrane space of mitochondria, thus dissipating the $\mathrm{H}+$ gradient across the inner membrane and uncoupling the respiratory chain. Perhaps more importantly, channel opening results in a volume disregulation of mitochondria due to the hyperosmolarity of the matrix, which causes the matrix space to expand.

Concerning the distribution of degeneration types, the pycnotic nucleus of the oocyte was the predominant sign of degeneration observed (Type 1 degeneration) in the control and after preservation at $4^{\circ} \mathrm{C}$. The greater rates of reduction of cellular metabolism may explain why there was not induction of other types of degeneration after preservation at $4^{\circ} \mathrm{C}$. Similar results were also observed after analysis of fresh (caprine: Bezerra et al., 1998; Lucci et al., 1999; and ovine: Jorio et al., 1991) or cold-stored preantral follicles at $4^{\circ} \mathrm{C}$ (feline: Wood et al., 1997). Jorio et al. (1991) showed that degeneration of the oocyte is the mode of atresia most frequently observed in preantral follicles. In vitro studies have shown that in certain preantral follicles the oocyte degenerates or completely disappears while granulosa cells appear healthy and continue to proliferate, showing that the oocyte is much more sensitive to degenerative events than granulosa cells (Braw-Tal and Yossefi, 1997 and Figueiredo et al., 1994). In contrast, in the treatments where the ovarian fragments were stored at 20 or $39^{\circ} \mathrm{C}, \mathrm{a}$ significantly higher percentage of degenerated oocyte and granulosa cells were observed. Under such conditions, oocyte and granulosa cells were equally affected by degenerative events. The changes observed in these follicles were probably induced by in vitro preservation conditions. These degenerated follicles exhibited a slightly or strongly retracted oocyte, with or without a pycnotic nucleus, and disorganized, low density granulosa cells, probably since they were enlarged in volume. The increase of preservation temperature from 4 to 20 and to $39^{\circ} \mathrm{C}$ and consequently increased oxygen consumption, associated with low oxygen tension in vitro may have caused the progressive increase of degenerated Types $2 \mathrm{~A}$ and $2 \mathrm{~B}$ follicles. The increase of the incubation time from 4 to 12 and to $24 \mathrm{~h}$ also increased the follicular injury caused by low oxygen tension in vitro. Jennings et al. (1975) suggested that hypoxic-induced changes in the cellular membrane permeability caused changes of intracellular $\mathrm{Na}+\mathrm{K}+$ and 
$\mathrm{Cl}-$, which together with an altered distribution of $\mathrm{Ca} 2+$ and increase of intracellular water, may lead to increased cellular volume and consequently cellular degeneration.

The earliest appearance of degenerated Types $2 \mathrm{~A}$ and $2 \mathrm{~B}$ follicles was observed after preservation of preantral follicles at 20 or $39^{\circ} \mathrm{C}$ in Braun-Collins solution in contrast to coconut water solution. Braun-Collins solution functions via hypothermic preservation in hyperosmotic solution, followed by a low cellular dehydration, thus avoiding consequent cell swelling. At greater temperatures, our results were similar to those obtained by Savioz et al. (1996) with kidney preservation at $14^{\circ} \mathrm{C}$. These authors demonstrated the lack of effectiveness of BraunCollins solution when its use was not associated with preservation at $4^{\circ} \mathrm{C}$. According to Figueiredo et al. (1994) retraction of the oocyte occurs during degeneration of preantral follicles. Thus, the early cellular dehydration provoked by Braun-Collins solution may have contributed to the initial oocyte retraction and consequently increased percentages of degenerated Types $2 \mathrm{~A}$ and $2 \mathrm{~B}$ follicles. In comparison, coconut water solution is iso-osmotic and has been successfully used for semen preservation in sheep (Guerra and Nunes, 1999), pigs (Toniolli et al., 1998) and humans species (Nunes, 1998). Coconut water solution also was as effective as TCM 199 during oocyte maturation (Blume et al., 1997a) and embryo culture (Blume et al., 1997b).

In conclusion, our study shows for the first time that initial proliferation of endoplasmic reticulum and damage to mitochondria are the first signs of degeneration in goat preantral follicles during storage in vitro. These structural changes progress with the increase of preservation temperature and incubation time. Thus, the understanding of events occurring in preantral follicles during in vitro degeneration might be very useful to optimize the systems of in vitro preservation as well as to understand follicular atresia.

\section{Acknowledgements}

This study was supported by the Laboratório de Histopatologia of Federal University of Pará and the Laboratório de Microscopia Eletrônica of University of Brasilia, Brazil. The authors thank Dr. L.D.M. Silva and Dr. Y. P. Quinet for comments on the manuscript.

\section{References}

Adams, E.C., Hertig, A.T., 1964. Studies on guinea pig oocytes. I. Electron microscopic observations on the development of cytoplasmic organelles in oocytes of primordial and primary follicles. J. Cell Biol. 21, 397-427. 
Adam, R., Astarcioglu, I., Raccuia, J.S., Ducot, B., Reynes, M., Bismuth, H., 1996. Beneficial effects of Eurocollins as aortic flush for the procurement of human lives. Transplantation 61, 705-709.

Assey, R.J., Hyttel, P., Kanuya, N., 1994. Oocyte structure in dominant and subordinate follicles in zebu cattle (Bos indicus). Anat. Embryol. 190, 461-468.

Bezerra, M.B., Rondina, D., Lima, A.K.F., Oliveira, L.C., Cecchi, R., Lucci, C.M., Giorgetti, A., Figueiredo, J.R., 1998. Aspectos quantitativos e qualitativos da foliculogênese na fase pré-natal na espécie caprina. Cienc. Anim. 8, 47-56.

Blume, H., Vale Filho, V.R., Marques Jr., A.P., Saturnino, H.M., 1997a. Avaliação da água de coco na maturação de oócitos bovinos. Rev. Bras. Reprod. Anim. 21, 72-75.

Blume, H., Vale Filho, V.R., Marques Jr., A.P., Saturnino, H.M., 1997b. Uso da água de coco no cultivo de embriões bovinos. Rev. Bras. Reprod. Anim. 21, 78-81.

Braw-Tal, R., Yossefi, S., 1997. Studies in vivo and in vitro on the initiation of follicle growth in the bovine ovary. J. Reprod. Fertil. 109, 165-171.

Butler, W.H., 1970. Ultrastructural studies on mitochondrial swelling. Biochem. J. 118, 883886.

Carroll, J., Whittingham, D.G., Wood, M.J., Telfer, E., Gosden, R.G., 1990. Extra-ovarian production of mature viable mouse oocytes from frozen primary follicles. J. Reprod. Fertil. 90, 321-327.

Cran, D.G., Moor, R.M., Hay, M.F., 1980. Fine structure of the sheep oocyte during antral follicles development. J. Reprod. Fertil. 59, 125-132.

Fair, T., Hulshof, S.C.J., Hyttel, P., Greve, T., Boland, M., 1997. Oocyte ultrastructure in bovine primordial to early tertiary follicles. Anat. Embryol. 196, 327-336.

Figueiredo, J.R., Hulshof, S.C.J., van den Hurk, R., Ectors, F.J., Fontes, R.S., Nusgens, B., Bevers, M.M., Beckers, J.F., 1993. Development of a combined new mechanical and enzymatic method for isolation of intact preantral follicles from fetal, calf and adult bovine ovaries.

Theriogenology 40, 789-799.

Figueiredo, J.R., Hulshof, S.C.J., van den Hurk, R., Nusgens, B., Bevers, M.M., Ectors, F.J., Beckers, J.F., 1994. Preservation of oocyte and granulosa cell morphology in bovine preantral follicles cultured in vitro. Theriogenology 41, 1333-1346.

Fuku, E., Xia, L., Downey, B.R., 1995. Ultrastructural changes in bovine oocytes cryopreserved by vitrification. Cryobiology 32, 139-156.

Fukuse, T., Hirata, T., Ueda, M., Hitomi, S., Wada, H., 1996. Effects of Euro-Collins, University of Wisconsin, and new extracelular-type trehalase-containing Kyoto solutions in an ex vivo rat lung preservation model. Transplantation 62, 1212-1217.

Green, D.R., Reed, J.C., 1998. Mitochondria and apoptosis. Science 281, 1309-1312. 
Guerra, F.F.A., Nunes, J.F., 1999. Fertilidade in vivo e avaliação in vitro do sêmen ovino resfriado e conservado em água de coco por 72 horas. Rev. Bras. Reprod. Anim. 23, 287-289.

Hay, M.F., Cran, D.G., Moor, R.M., 1976. Structural changes occurring during atresia in sheep ovarian follicles. Cell Tissue Res. 169, 515-529.

Hertig, A.T., Adams, E.C., 1967. Studies on the human oocyte and its follicle. I. Ultrastructural and histochemical observation on the primordial follicle stage. J. Cell Biol. 34, 647-675.

Hyttel, P., Xu, K.P., Smith, S., Greve, T., 1986. Ultrastructure of in vitro oocyte maturation in cattle. J. Reprod. Fertil. 78, 615-625.

Jennings, R.B., Ganote, C.E., Reimer, K.A., 1975. Ischemic tissue injury. Am. J. Pathol. 81, 179198.

Jorio, A., Mariana, J.C., Lahlou-Kassi, A., 1991. Development of the population of ovarian follicles during the prepubertal period in D'man and Timahdite sheep. Anim. Reprod. Sci. 26, 239-250.

Kruip, T.A.M., Cran, D.G., van Beneden, T.H., Dieleman, S.J., 1983. Structural changes in bovine oocytes during final maturation in vivo. Gamete Res. 8, 29-47.

Lucci, C.M., Amorin, C.A., Báo, S.N., Figueiredo, J.R., Rodrigues, A.P.R., Silva, J.R.V., Gonçalves, P.B.D., 1999. Effect of the interval of serial sections of ovarian tissue in the tissue chopper on the number of isolated caprine preantral follicles. Anim. Reprod. Sci. 56, 39-49.

Lucci, C.M., Carvalho, F.C.A., Silva, J.R.V., Figueiredo, J.R., Báo, S.N., 2001. Morphological and ultrastructural characterization of goat preantral follicles. Small Rum. Res., in press. Nunes, J.F., 1998. Utilização da água de coco como diluidor do sêmen de animais domésticos e do homem. Rev. Bras. Reprod. Anim. 22, 109-112.

Oktay, K., Nugent, D., Newton, H., Salha, O., Chatterjee, P., Gosden, R.G., 1997. Isolation and characterization of primordial follicles from fresh and cryopreserved human ovarian tissue. Fertil. Steril. 67, 481-486.

O'Shea, J.D., Hay, M.F., Cran, D.G., 1978. Ultrastructural changes in the theca interna during follicular atresia in sheep. J. Reprod. Fertil. 54, 187-187.

Savioz, D., Bolle, J.F., Graf, J.D., Jeanjacquot, A., Savioz, M., Dietler, G., Favre, H., Leski, M., Morel, D., Morel, P., 1996. Kinetics of cellular viability in warm versus cold ischemia conditions of kidney preservation. Transplantation 62, 414-417.

Sharma, R.K., Sawiiney, A.K., Vats, R., 1994. Cytoplasm fine structure of the primordial oocytes of goat. Indian J. Anim. Sci. 64, 1354-1356.

Silva, J.R.V., Carvalho, F.C.A., Lucci, C.M., Santos, R.R., Figueiredo, J.R., 1999. Conservação de folículos pré-antrais caprinos em solução a base de água de coco. Cienc. Anim. 9, 27-36.

Silva, J.R.V., Lucci, C.M., Carvalho, F.C.A., Báo, S.N., Costa, S.H.F., Santos, R.R., Figueiredo, J.R., 2000. Effect of coconut water and Braun-Collins solutions at different temperatures and incubation times on the morphology of goat preantral follicles preserved in vitro.

Theriogenology 54, 809-822. 
Tassel, R., Kennedy, J.P., 1980. Early follicular development and atretic changes in ovary of the lamb - fine structure and histochemistry. Aust. J. Bio. Sci. 33, 675-687.

Toniolli, R., Mesquita, D.S.M., Cavalcante, S.G., 1998. Avaliação in vitro do sêmen su'ı́no dilu' Ido em BTS e na água de coco in natura e estabilizada. Rev. Bras. Reprod. Anim. 22, 198201.

van den Hurk, R., Spek, E.R., Hage, W.J., Fair, T., Ralph, J.H., Schotanus, K., 1998. Ultrastructure and viability of isolated bovine preantral follicles. Hum. Reprod. Update 4, 833-841.

van Wezel, I.L., Rodgers, R.J., 1996. Morphological characterization of bovine primordial follicles and their environment in vivo. Biol. Reprod. 55, 1003-1011.

Wassarman, P.M., Josefowicz, W.J., 1978. Oocyte development in the mouse: an ultrastructural comparison of oocytes isolated at various stages of growth and meiotic competence. J. Morphol. 156, 209-236.

Wood, T.C., Montali, R.J., Wildt, D.E., 1997. Follicle-oocyte atresia and temporal taphonomy in cold-stored domestic cat ovaries. Mol. Reprod. Develop. 46, 190-200. 